\title{
KANT'S MORAL THEISM AND MORAL DESPAIR ARGUMENT AGAINST ATHEISM
}

\author{
STIJN VAN IMPE
}

Ghent University, Belgium

\author{
[Final accepted draft: not for quotation. For published article, see \\ http://onlinelibrary.wiley.com/doi/10.1111/j.1468-2265.2010.00656.x/abstract]
}

In the Critique of Pure Reason, Kant rejects the traditional metaphysical - i.e., the ontological, cosmological and physico-theological (or teleological) - proofs for God's existence. ${ }^{1}$ In the Groundwork of the Metaphysics of Morals, Kant argues that our duties are not grounded in the divine will, but solely in the moral law (GMS IV:431). ${ }^{2}$ Otherwise, morality would be based on religion, which would amount to theological morality and heteronomy. Hence, faith in God seems to be no requisite for a virtuous life and atheism seems to be compatible with morality within Kant's philosophy. Yet, in many of his other works, including the Critique of Practical Reason, Critique of Judgment, Religion within the Boundaries of Mere Reason and his lesser known Lectures on the Philosophical Doctrine of Religion, Kant argues that 'morality leads inevitably to religion' (KPV V:125; RGV VI:6) and insists that faith in God is necessary for the intelligibility of the possibility of the highest good as the final end of the moral law. Furthermore, Kant condemns atheism on moral grounds arguing that - by rejecting the idea of God as a sufficient cause of the highest good - it rules out additional religious incentives to morality (KRV A 812 / B 841), ${ }^{3}$ leads to moral despair, weakens respect for the moral law, damages the moral disposition (KU V:540), and has a pernicious influence on society by causing social disorder (WDO VIII:146) and by robbing citizens of incentives to morality viewed as commanded and enforced by God (V-MS/Vigilantius XXVII:531). ${ }^{4}$ This paper particularly seeks to explore (1) Kant's moral criticism in the Critique of Judgment that atheism leads to moral despair by lacking the cognitively determinate and psychological reassuring view offered by rational faith for rendering the possibility of the highest good, i.e., the harmonious and proportionate union of virtue and happiness, intelligible, and (2) the rational, non-theistic alternatives that atheists can embrace for upholding the possibility of the highest good. Before tackling these issues, I shall start by offering a brief analysis of Kant's defence of moral theism and his conception of atheism. 


\section{KANT'S MORAL THEISM}

Kant describes moral theism as faith in God based on morality, viz. 'a conviction of the existence of God on practical grounds' (V-Th/Volckmann XXVIII:1151). ${ }^{5}$ In comparison to deism, moral theism 'does not think of God according to nature, but according to morality' and thus conceives God as 'the lawgiver in the realm of morals' (V-Th/Volckmann XXVIII:1152), 'the author of our moral laws', 'the ruler of the world' - and not merely as the 'author' of the world (V-Phil-Th/Pölitz XXVIII:1002). Kant distinguishes faith (Glaube) from both knowledge (Wissen) and opinion (Meinung). Although having an opinion, believing and knowing all involve the 'subjective validity of judgment' or 'taking something to be true', Kant distinguishes them as follows:

Having an opinion is taking something to be true with the consciousness that it is subjectively as well as objectively insufficient. If taking something to be true is only subjectively sufficient and is at the same time held to be objectively insufficient, then it is called believing. Finally, when taking something to be true is both subjectively and objectively sufficient it is called knowing. Subjective sufficiency is called conviction (for myself), objective sufficiency, certainty (for everyone). (KRV A 822 / B 850) ${ }^{7}$

Whereas knowledge can count on 'certainty' or 'objective sufficiency', i.e., valid theoretical grounds, faith or belief can only rely on 'conviction' or 'subjective sufficiency', i.e., valid practical grounds. Faith thus requires having valid practical grounds for holding something to be true, whereas it lacks valid theoretical grounds for doing so. Although practical arguments are insufficient to claim that we know that there is a God, they do provide us with 'moral certainty' that God exists (KRV A 828-30 / B 856-8). This moral certainty rests on an entirely personal basis: 'I must not even say "It is morally certain that there is a God," etc., but rather "I am morally certain" etc.' (KRV A 829 / B 857). Furthermore, Kant holds that speculative arguments cannot undermine moral faith in God (KPV V:134, 143) for our faith is 'unshakeable, and it can never be overthrown, not even if all mankind united to undermine it' (V-Phil-Th/Pölitz XXVIII:1011). ${ }^{8}$ The moral theist thus

needs no speculative proofs of the existence of God; he is convinced [überzeugt] of it with certainty, because otherwise he would have to reject the necessary laws of morality which are grounded in the nature of his being. ${ }^{9}$ Thus he derives theology from morality, 
yet not from speculative but from practical evidence; i.e. not though knowledge but from faith. (V-Phil-Th/Pölitz XXVIII:1012)

Kant uses a distinctly moral view of God. ${ }^{10}$ Kant depicts God as punishing evil and rewarding good (V-Phil-Th/Pölitz XXVIII:1085). ${ }^{11}$ In addition to the scholastic attributes of omniscience, omnipresence, and omnipotence, Kant ascribes to God the moral attributes of holiness, beneficence, and justice (V-Phil-Th/Pölitz XXVIII:1012, 1073-5). ${ }^{12}$ Kant views God not only as the 'moral legislator' and 'author of the moral law' (V-MS/Vigilantius XXVII:530), ${ }^{13}$ but also as the 'personification' of that law (V-Phil-Th/Pölitz XXVIII:1076, $1091)^{14}$ or as 'personified morality' (V-MP/Dohna XXVIII:700). ${ }^{15}$ God is a moral 'person' (OP XXI:9-10) ${ }^{16}$, i.e. a purely rational being that - in contrast to man - always lives up to the moral law and hence embodies this law as it were. God is particularly 'a person to which all human duties are at the same time the commands of this person' (OP XXII:119). ${ }^{17}$ Hence, Kant emphasizes that all our moral duties can be regarded as 'divine commands' (KPV V:129; RGV VI:153, OP XXII:120). God is also the only being that is capable of scrutinizing and fathoming the 'intelligible ground of the heart', i.e., all maxims of man's power of choice [Willkur] and his moral dispositions, and hence of distinguishing between who is virtuous, prudent, or vicious (RGV VI:48). Finally, Kant views God as being concerned with the realisation of the highest good, i.e., the harmonious union of maximal virtue and proportionate happiness, and the exact harmony of the realm of nature (Reich der Natur), i.e., the world as it is according to mechanical laws of nature, and the realm of ends (Reich der Zwecke), i.e., the world as it ought to be according to moral laws of freedom (V-Phil-Th/Pölitz XXVIII:1116). ${ }^{18}$ God thus has a moral plan for mankind (KPV V:125; KU V:450). Faith in God guarantees us that our moral endeavours are not in vain, viz. that they necessarily produce their intended good ends, and that if we do what we can and ought to do in approximating the highest good, God will complete our task (KU V:450-3; RGV VI:74-7, 98, 192, 201-2). ${ }^{19}$

Kant's practical arguments in favour of rational faith in God - as elaborated in the second Critique (KPV V:110-14, 124-46) ${ }^{20}$ - are directed to the possibility of the highest good. Kant's argument starts from the unquestionable validity of the moral law as a fact of reason. This law commands categorically through reason. If the moral law commands us to pursue the highest good as the final end, we have to do so and the highest good has to be possible (KPV $\mathrm{V}: 57)$. If this were not to be the case, we would not act rationally - for rational agency entails that if we intend an end by our agency, it should be possible to realise this end - and the moral law that commands us to seek this end would be invalid. However, given our finite (physical) 
capacities and the amoral nature of the world, which does not systematically connect virtue with proportionate happiness, it remains unclear how we are to establish the highest good. Yet, if there were an omnipotent, omniscient, omnipresent author of the world who is at the same time a holy, beneficent and just world ruler, i.e., God according to moral theism, such a being could supplement our limited endeavours and complete the realisation of the highest good. Since theoretical reason cannot demonstrate the impossibility of God's existence and rational faith in God does not conflict with theoretical reason, we are justified in assuming the existence of God (KPV 135-43). Moreover, Kant argues that rational faith in God is the only cognitive pathway for understanding how the highest good is to be brought about. Hence, he concludes that we have to believe in God (KPV V:125-6, 142-6). Faith in God is thus grounded in the necessity of being able to think the possibility of the highest good so that we can rationally execute the commands of the moral law. ${ }^{21}$ Precisely for this reason, Kant argues that faith in God is morally necessary and that morality inevitably leads to religion (KPV V:125, RGV VI:6) in this sense that religion, while not being necessary for grounding the principles of morality, is necessary for rendering the completion of the final object of morality intelligible. Consequently, Kant contends that if one doubts the possibility of God's existence, one has to give up the highest good and consequently 'hold all moral laws for empty imagination' (R XVIII:556). ${ }^{22}$

\section{KANT'S VIEWS ON ATHEISM}

Throughout his different Lectures on the Philosophical Doctrine of Religion and Reflexionen, Kant discusses two kinds of atheism: sceptical atheism or 'Ohnegötterei' and dogmatic atheism or 'Gottesläugnung' (V-Th/Volckmann XXVIII:171). ${ }^{23}$ Whereas the sceptical atheist denies all knowledge (Erkenntnis) and conviction (Überzeugung) of God's existence and thus rejects all (speculative) proofs for God's existence (Dasein), the dogmatic atheist denies the possibility of (the concept of the existence) of God itself (R XVIII:520) ${ }^{24}$ and contends that 'there is no God' (V-Th/Volckmann XXVIII:1171). ${ }^{25}$ In other words, 'the dogmatic atheist (the denier of God) denies the possibility [of God's existence], the sceptical atheist (the one who is without Godship) denies all evidence of [God's] existence. The former [denies] the concept, the latter [denies] the ground of proof' (R XVIII:541). ${ }^{26}$ The sceptical atheist thus considers speculative arguments as insufficient for proving God's existence (VTh/Volckmann XXVIII:1175). ${ }^{27}$ Yet, at the same time, he also recognises that such arguments fail to prove that God does not exist (V-Th/Volckmann XXVIII:1151). ${ }^{28}$ For this reason, Kant 
argues that the sceptical atheist can be convinced to adopt rational faith in God on the basis of moral considerations (V-Th/Volckmann XXVIII:1175). ${ }^{29}$ In spite of the insufficiency of speculative proofs of God's existence, Kant thinks that we cannot doubt God's existence for this reason for we still have 'practical proofs' (V-Th/Baumbach XXVIII:1257). The sceptical atheist thus regards God not merely as a logical but as a real possibility from a practical point of view and as a speculatively permissible and morally necessary hypothesis 'since the moral laws find a surer entry thereby, and are more easily followed' (V-MS/Vigilantius XXVII:530). By contrast, the dogmatic atheist radically denies the existence of God: he regards it neither as a logical, nor as a real possibility.

Furthermore, Kant contends that only the dogmatic atheist is to be contrasted to the moral theist (V-Phil-Th/Pölitz XXVIII:1010) ${ }^{30}$ arguing that the sceptical atheist 'can still have religion, because he sincerely admits that it is even more impossible to prove that there is no God than to prove that there is one. [...] Now the belief in a merely possible God as ruler of the world is obviously the minimum of theology' (V-Phil-Th/Pölitz XXVIII:1010). ${ }^{31}$ Although the sceptical atheist denies all knowledge of God's existence, he assumes the possibility of God on the basis of moral considerations and conducts himself as if there is a God so that he is religious after all (V-Th/Volckmann XXVIII:1151). Kant thus assumes that a sceptical atheist, while being an atheist from a speculative point of view, can be a moral theist from a practical point of view: 'Atheism can reside in mere speculation, while in practice [Praxis] such a person can be a theist or venerator of God' (V-Mo/Collins XXVII:312). ${ }^{32}$ The sceptical atheist can thus have religion by adopting moral theism on practical grounds. In fact, given Kant's philosophical views on the existence of God as defended throughout his entire mature oeuvre and lectures, Kant himself is a 'sceptical atheist' from the standpoint of theoretical reason, i.e., one who stays unconvinced by the theoretical arguments for God's existence, but who is open to positing this existence if it in fact proves necessary to conceive the realisability of the highest good, a condition which Kant firmly asserts and which makes him therefore a 'moral theist' from the standpoint of practical reason. Kant's own position thus also implies that the only kind of theism that is at all intellectually honest and respectable is 'moral theism', never 'dogmatic' or 'theoretical theism, ${ }^{33}$

In comparison to the sceptical atheist, Kant thinks that the dogmatic atheist commits a crucial intellectual error by denying God's existence: the dogmatic atheist claims to know that God does not exist, which is impossible according to Kant. The dogmatic atheist has to prove $a$ priori that God does not exist by showing that the concept of God itself contradicts itself in 
the union of its predicates (V-Th/Volckmann XXVIII:1171-2). Although Kant recognises that an a priori proof of God's existence is not possible because of our incapability to have insight into how a synthesis of all possible perfections may be possible, he argues against the dogmatic atheist that - because of the same lack of insight - 'it is also impossible for human reason ever to prove that such a combination of all perfections in one thing is not possible' (V-Phil-Th/Pölitz XXVIII:1025-6). Hence, Kant concludes:

Reason itself is not able to prove with apodictic certainty any such possibility [of God]. For this would require an insight which far transcends the bounds of the human faculty of reason. But from this same inability of my reason follows the impossibility of ever proving that a most perfect being is not possible. And thus collapses the edifice of the dogmatic atheist. For if he wishes to deny God's existence and assert that there absolutely is no God, the atheist must first demonstrate the impossibility of God. But here reason forsakes him, and everything he may bring against the possibility of God will be only so much absurdity and nonsense. (V-Phil-Th/Pölitz XXVIII:1026). ${ }^{34}$

Although speculative arguments cannot establish that God exists, they can thus neither establish that God does not exist. Moreover, it is cognitively legitimate to assume the possibility of God's existence and the moral theist finds in pure practical reason convincing moral grounds for embracing faith in God and affirming his existence. The dogmatic atheist, on the other hand, commits an intellectual error in denying the possibility of God's existence for he claims to know the unknowable and to be able to prove a priori the improvable. ${ }^{35}$ Kant's theoretical rejection of dogmatic atheism also affects his moral view of it. Kant concludes that dogmatic atheists are morally evil and that their will is corrupted for they affirm that God does not exist while they ought to recognise that they have no ground for doing so. In this respect, Kant once again contrasts the sceptical with the dogmatic atheist. From a moral point of view, sceptical atheists are far better off than dogmatic atheists for the former 'who have fallen into atheism through speculation should not be so readily condemned for wickedness [...]; only their understanding was corrupted, not their will' (italics added) (VMo/Collins XXVII:311). ${ }^{36}$ Kant thus reasons that if the 'logical ground' for atheism does not hold, the dogmatic atheist thus 'denies God from wantonness [muthwillig] and lack of respect for the better conviction' and thus embraces a 'moral ground' for his atheism (V-PP/Herder XXVII:11). ${ }^{37}$ In the next section, I shall examine one specific kind of 'wickedness of the heart', viz. abandoning the highest good and lapsing into moral despair. 


\section{KANT'S MORAL DESPAIR ARGUMENT: ANALYSIS AND REPLY}

Kant's criticism that atheism leads to moral despair is most fiercely expressed in the Critique of Judgment, where Kant conceives of 'a righteous man' who is convinced that there is no God and who would merely unselfishly try to establish the highest good (KU 5:452). Yet, so Kant argues,

his effort is limited; and from nature he can, to be sure, expect some contingent assistance here and there, but never a lawlike agreement in accordance with constant rules [...] with the ends to act in behalf of which he feels himself bound and impelled. Deceit, violence, and envy will always surround him, even though he is himself honest, peaceable, and benevolent; and the righteous ones besides himself that he will still encounter will, in spite of all their worthiness to be happy, nevertheless be subject by nature, which pays no attention to that, to all the evils of poverty, illnesses, and untimely death, [...] and will always remain thus until one wide grave engulfs them all together (whether honest or dishonest, it makes no difference here) and flings them [...] back into the abyss of the purposeless chaos of matter from which they were drawn. The end, therefore, which this well-intentioned person had and should have had before his eyes in his conformity to the moral law, he would certainly have to give up as impossible; or, if he would remain attached to the appeal of his inner moral vocation and not weaken the respect, by which the moral law immediately influences him to obedience, by the nullity of the only idealistic final end that is adequate to its high demand (which cannot occur without damage to the moral disposition), then he must assume the existence of a moral author of the world, i.e., of God, from a practical point of view, i.e., in order to form a concept of at least the possibility of the final end that is prescribed to him by morality. (KU 5:452-3)

Marina echoes Kant's argument that the moral subject rejecting faith in God 'would eventually have to collapse in despair' as follows:

For she would have to believe that she, and other individuals like her, were engaged in a project that, irrespective of its moral worth, was doomed to failure. Battling against a hostile and indifferent universe whose cataclysmic upheavals consume the just and the 
unjust alike, [...] she could only conclude that death and the chaos of nature will eventually claim her and all others like her. Not to grasp the horror of the inevitable annihilation that a purposeless nature poses to a moral yet finite individual could only be an intentional blindness. It is to continue to engage in a battle towards the acquisition of virtue, the inevitable outcome of which is known beforehand; as such, it is to display the courage of a fool. If she reasons correctly, she will see that given the premise that she is merely the product of a blind and chaotic nature, the moral law [...] would thus have been exposed as an idle and fantastic dream. ${ }^{38}$

As we shall see, Kant makes several seemingly interconnected but highly questionable claims presented in some kind of slippery slope argument. Kant's argument can be reconstructed as follows. Its premises are: (P1) the amoral nature of the world, the failings and sufferings of the righteous and the futility of their moral endeavours offer no perspectives for establishing the highest good; (P2) moral theism offers the only concept, i.e., the existence of an omnipotent, intelligent and just moral world ruler, for rendering the possibility of the highest good intelligible; (P3) atheism rejects the concept described in (P2). Its main conclusions are: (C1) an atheist has to abandon the highest good; and (C2) atheism leads to moral despair. It is this argument that I challenge. My strategy consists in questioning and undercutting Kant's premises as well as in distinguishing between an 'ideal-transcendent' account of the highest good as the proportionate and systematic union of virtue and happiness and a 'historicalimmanent' account of the highest good as the creation of a moral world characterised by happiness conditioned by virtue and morality, which will be far more appealing for even the most rabid atheist.

Let us start with Kant's third premise. Following Kant's own account of atheism, this premise need not necessarily apply to the sceptical atheist. As we have seen, sceptical atheists can still recognise the possibility that God may exist on the basis of moral considerations and can thus conceive of at least one cognitively determinate pathway to be able to think the attainability of the highest good. Yet, as Denis rightly remarks, Kant's account obscures 'how skeptical atheism constitutes a distinct theological position' by omitting the fact that 'skeptical atheism implies neither a practical faith in God, nor a rejection of that faith'. In fact, Kant makes two mistakes, viz. (i) by presupposing that the sceptical atheist does actually accept God's existence on the basis of moral considerations and thus by positing an equivalence between assuming the possibility of God and affirming the existence of God, and (ii) by omitting the distinction between sceptical atheists "who embrace faith in God, and those who do not - i.e., 
those who live with the recognition that God may exist, without themselves affirming that God does exist. ${ }^{39}$ Sceptical atheists may thus recognise that God might exist without affirming God's existence on the basis of moral considerations. Kant's third premise therefore only applies to those sceptical atheists who cannot be convinced by moral considerations to affirm faith in God's existence, and to dogmatic atheists.

Let us now consider Kant's second premise. Is Kant right in arguing that moral faith in (the idea of) God as a just world ruler provides the only concept for embracing the possibility of the highest good? If we could conceive non-theistic, moral-teleological accounts that render the highest good intelligible, the atheist would not have to abandon the possibility of the highest good. Indeed, while denying the existence of God, an atheist can still commit himself - because of the authority of the moral law directing an agent to pursue the highest good - to embrace some non-theistic, moral-teleological schema that suffices to be able to think the possibility of the highest good. An atheist can assume an intelligent, rational world order through which a moral teleology necessary for establishing the highest good can be presupposed. For example, Fichte holds that the morally well-disposed subject believes that the world in which he acts is in conformity with his moral actions without believing in (the idea of) a personal and transcendent God over and above this impersonal, rational and teleological world order. Theravada Buddhism embraces the concept of karma as a moralteleological mechanism that is operative in nature and that lets us think a harmony of virtue and happiness but that does not appeal to a God. By analogy, an atheist may dismiss moral theism and yet ground the possibility of the highest good in some (unknown) moralteleological mechanism in nature through which the natural and the moral world are brought into harmony and through which the highest good will be attained by virtue of moral agency. A drawback to such an account seems to be that it is less cognitively determinate and specific than Kant's moral theism regarding the precise mechanism of how the highest good is to be brought about. Yet, as Byrne notices, avoiding commitment to 'metaphysical assumptions containing rich pictures of the possible mechanism behind moral teleology is more "Critical" than Kant's own apparatus of postulates. ${ }^{40}$ Hence, an atheist embracing the possibility of a non-theistic conception of the realisation of the highest good need not necessarily succumb into moral despair.

Moreover, in the Critique of Practical Reason, Kant himself seems to consider the possibility of a non-theistic, natural-teleological conception of the realisation of the highest good: 
I said above that in accordance with a mere course of nature in the world happiness in exact conformity with moral worth is not to be expected and is to be held impossible, and that therefore the possibility of the highest good [...] can be granted only on the presupposition of a moral author in the world. [...] In fact, the impossibility referred to is merely subjective, that is, our reason finds it impossible for it to conceive, in the mere course of nature, a connection so exactly proportioned and thoroughly purposive between events occurring in the world in accordance with such different laws, although, as with everything else in nature that is purposive, it nevertheless cannot prove - that is, set forth sufficiently on objective grounds - the impossibility of it in accordance with universal laws of nature. (KPV V:145)

Kant thus argues that - objectively speaking - there are two equal possibilities for conceiving the highest good: moral theism and natural teleology. He concedes that objective grounds for the possibility that nature itself provides the unification of virtue and happiness in accordance with its own natural laws cannot be ruled out. However, so Kant argues, since human reason is not capable of fathoming in detail how the latter possibility has to be conceived, he concludes that there are compelling subjective grounds for human reason to dispense with this possibility and to prefer the theistic conception of how the highest good is to be brought about:

But as for the way we are to represent this possibility [of the highest good], whether in accordance with universal laws of nature without a wise author presiding over nature or only on the supposition of such an author, reason cannot decide this objectively. Now a subjective condition of reason enters into this, the only way in which it is theoretically possible for it to think the exact harmony of the realm of nature with the realm of morals as the condition of the possibility of the highest good, and at the same time the only way that is conducive to morality. (KPV V:145)

Both moral theism and natural teleology are thus two objectively equal ways to represent the possibility of the highest good. The difference between these two options is that the latter is cognitively less determinate and specific: it falls beyond the scope of our reason to conceive how natural teleological laws may establish an exact proportion of happiness and virtue, whereas faith in God as moral world ruler does seem to provide us with a more vivid and concrete account of the possibility of such a harmony. Kant thus concludes that human beings will prefer moral theism for conceiving the possibility of the highest good because the 
postulate of God is subjectively more comprehensible to our human cognitive faculties than a view according to which the highest good would be in conformity with mere laws of nature. ${ }^{41}$ Yet, it is important to keep in mind that Kant himself concedes the validity of appealing to a natural teleological world order as an objective alternative for considering the possibility of the highest good without appealing to a supersensible entity. As such, Kant implicitly provides the atheist with a non-theistic account for affirming the possibility of the highest good. And although Kant thinks that moral theism is subjectively more attractive or persuasive for human reason by offering a more specific and determinate account of how the highest good may be brought about, he has no conclusive objective arguments for tipping the balance in favour of moral theism.

However, appealing to some non-theistic, metaphysical schemes such as a teleological world order for guaranteeing the possibility of the highest good may be a leap to far for some radical atheists as it still relies on some kind of metaphysical faith. Moreover, an atheist may also advocate a Darwinian view on nature and reject the existence of a teleological world order. Yet, even such atheists can still uphold the possibility of the highest good by adopting the moderate epistemic stance that - in spite of what Kant thinks - the impossibility of the highest good is not sufficiently or objectively proven and hence recognise - because of their commitment to the moral law - that the highest good is something valuable to be pursued. As long as there is no sufficient, objective proof for the impossibility of the highest good, there is no reason to regard our moral efforts for realising it as irrational, especially if it is our wellconsidered free and rational choice to put great value on this moral ideal. This sceptical rationality claim yields a stance that is genuinely 'critical' and that is more consistent with present-day scientific insights and growing secular pluralism in ethics.

The idea that it is not irrational to pursue the highest good as long as its impossibility is not proven is not unfamiliar to Kant's philosophy. Both in On the Common Saying and the Metaphysics of Morals, Kant contends that in the case of an end set as a duty it suffices that its possibility is not demonstrably impossible in order to render its pursuit rational. ${ }^{42}$ In On the Common Saying, he argues that the thought that a moral end has not yet been realised and for this reason will probably be never realised does not in itself justify to abandon this end 'as long as its achievement is not demonstrably impossible' (TP VIII:309-10). Kant thus argues that if an end is morally valuable, the absence of proof of the impossibility of it suffices to render our efforts in its behalf rational. In the Metaphysics of Morals, Kant argues that our duty consists in acting in accordance with the idea of a moral end 'even if there is not the least theoretical probability that it can be achieved, as long as its impossibility cannot be 
demonstrated either' (MS VI:354). Once more, Kant contends that if it is a duty to achieve an end, all that is needed to make the pursuit of that end rational is not a guarantee that it can be achieved, but rather the absence of a demonstration that it cannot be achieved. The idea that rational agency directed to pursuing an end set as a duty only requires that the impossibility of the end is not proven - rather than that its possibility has to be proven by postulating God as moral world ruler - provides the atheist with a genuine and rationally stable alternative to moral theism in order not the abandon the highest good.

However, in defence of Kant, it might be argued that the atheist's approach keeps it dangling how the systematicity and proportionality of virtue and happiness as core feature of the highest good can be guaranteed. Although it suffices to be convinced that the attainment of the highest good is not per se impossible in order to be able to rationally pursue it, one might question whether such an approach suffices for conceiving a systematic and necessary harmony - instead of a merely contingent aggregate - of virtue and happiness in the highest good. It is precisely this feature of systematicity that Kant thinks a righteous atheist like Spinoza lacks in conceptualising the possibility of the highest good. Yet, as we shall see, there are also strands in Kant's philosophy that do not primarily emphasise this systematic and proportionate union of virtue and happiness, but rather advocate an account of the highest good as a moral world of virtue and happiness conditioned by morality. Furthermore, we can stick to the argument that as long as there is no proof for the impossibility per se of some harmonious system of virtue and happiness, there is no reason to conclude that we act irrationally in striving for such a system. With respect to the question of how such a system might be conceived and thought, it seems that Kant's ethico-theology provides us with a cognitively determinate and - perhaps above all - a psychologically reassuring, hence subjectively more attractive view on the realisability of the highest good:

The cognition of God must therefore complete morality, but it must not first determine whether something is morally good or a duty for me! This I must judge from the nature of things in accordance with a possible system of ends; and I must be just as certain of it as I am that a triangle has three angles. But in order to provide my heart with conviction, weight and emphasis, I have need of a God who will make me participate in happiness in accordance with these eternal and unchangeable laws, if I am worthy of it. (italics added) (V-Phil-Th/Pölitz XXVIII:1116-7) ${ }^{43}$ 
Let us proceed with another consideration in undercutting Kant's moral despair argument against atheism. If Kant were really to succeed in arguing that moral theism offers the only pathway for guaranteeing the possibility of the highest good, he would also have to prove its impossibility in case of a lack of faith. But Kant has no real sufficient, objective arguments for this. This is where Kant's first premise comes in. In fact, Kant relies mainly on empirical or subjective evidence according to which the world's amoral nature and the failures and sufferings of the righteous rule out the success of man's moral actions, display their futility and prove the (empirical) impossibility of the highest good. Yet Kant's evidence here is rooted in a pessimistic anthropological worldview, which is at odds with his optimistic beliefs about the final destiny of mankind in his Lectures on Ethics and On the Common Saying, where he argues that many proofs show that in the course of history the human race has made a substantial progress toward self-perfection (V-Mo/Collins XXVII:470-1; TP VIII:310). Surely, the world taken as a realm of nature is completely amoral and we cannot deny that we are faced with sufferings and failures even of the most virtuous and righteous people. But, contra Kant, I contend that there are enough reasons to be more optimistic in this regard. Despite all its cruelties, mankind's history has also abundantly shown its moral successes, such as the abolition of slavery, the spreading of democratic regimes, the promotion of equality between men and women, the institution of international human rights organizations, the right to free public opinion and speech, and so on. As Denis rightly notes:

despite Kant's observations about the amoral nature of the world [...], our day to day lives give us ample reason to see the world as amenable to our efforts. More often than not, what we intend to bring about through our morally-intended actions does come about. Even when things do not go as well as we would wish, we usually make things better than they would be if we had not tried. ${ }^{44}$

Viewed as such, Kant's first premise seems to be first and foremost rooted in a particular and pessimistic anthropological stanza and hence can neither appeal to universality, nor to objectivity. Moreover, in On the Common Saying, Kant himself recognises that 'empirical evidence against the success of [...] resolves undertaken on hope does not count for anything' (TP VIII:309). Hence, an atheist who recognises that the impossibility of the highest good is not objectively proven and who is confident in the future, does not have to abandon the highest good and does not need to succumb into moral despair. Furthermore, as Wood points 
out, Kant's view that the amorality of the world and the suffering of the righteous yield moral despair is only provisional and hence limited:

Such a despair must always be premature, in the sense that it is always beyond the power of a finite being to know absolutely that the world is destitute of moral goodness, that it provides no ground for the realization of his final end. His despair is always therefore a presumptuous judgment about the world. [...] The uncertainty of the world and the finitude of his knowledge rather leave man suspended between hope and despair. $^{45}$

Although man's natural condition may seem to exhaust hope, as Kant holds, it does not refute it altogether and there are ample counterexamples furnishing evidence that confidence in a morally better future is not unwarranted.

Finally, dogmatic atheists may also bypass Kant's 'ideal-transcendent' conception of the highest good as happiness proportionate to virtue and restrict themselves to Kant's 'historical-immanent' conception of the highest good as the creation of a moral world of virtue and happiness conditioned by morality, the possibility of which depends on human but not divine - agency. ${ }^{46}$ The former account is 'ideal-transcendent' because it refers to the unconditioned final end of pure practical reason as a 'mere object of thought', ${ }^{47}$ and because the intelligibility of its realisation depends on assuming the existence of a moral world ruler and the immortality of the soul. Hence, it is also a 'theistic' account of the highest good. The latter account is 'historical-immanent' because it refers to a social end to be pursued collectively by the human race in this world over the course of history. Hence, it is also a 'non-theistic' account of the highest good. While Kant's 'ideal-transcendent' account as happiness in perfect proportion to virtue is predominant in his philosophy, ${ }^{48}$ some passages (TP VIII:279-80; RGV VI:5, 97-8; KU V:450, 453) suggest a 'secular', 'historicalimmanent' account of the highest good as 'the existence of rational beings subject to moral laws' (KU V:444) or, as Denis puts it, 'a world of virtue, justice, and happiness, and flourishing rational capacities'. ${ }^{49}$ This account of the highest good does not so much stress the systematic proportionality between happiness and virtue, but rather happiness in conformity to or conditioned by moral agency and virtue. This account acknowledges the importance and necessity of happiness but makes its value dependent upon the morality of the maxims on which it is pursued. ${ }^{50}$ Hence, the realisation of the 'historical-immanent' highest good does not depend on the existence of God and the immortality of the soul, and offers a more fruitful 
account that is suitable to serve as the end of our autonomous moral conduct and that lies entirely within the scope of our human agency. Adopting this 'historical-immanent' account of the highest good provides even the most rabid atheist with a legitimate alternative to moral theism for affirming the possibility of the highest good and hence for resisting moral despair.

\section{CONCLUSIONS}

In spite of his rejection of the traditional metaphysical proofs of God's existence, Kant defends moral theism, i.e. a subjective, rational conviction in the existence of God as a moral world ruler on behalf of the intelligibility of the highest good as the final end of the moral law. In the third Critique, Kant argues that atheism leads to moral despair by rejecting moral theism as the sole cognitively determinate and psychologically reassuring view for rendering the highest good intelligible. Yet an atheist can invoke different strategies for refuting Kant's argument: (1) adopting some non-theistic, moral-teleological world conception through which the highest good can be conceived, (2) adopting a natural teleology through which nature itself is conceived as the ground for the highest good, (3) adopting the modest epistemological stance that striving for the highest good is not irrational as long as its impossibility is not sufficiently demonstrated, (4) showing that Kant has not objectively proven the impossibility of the highest good in case of a lack of faith in God, and (5) appealing to an alternative historical-immanent account of the highest good as the creation of a moral world of virtue and happiness conditioned by morality. ${ }^{51}$

\footnotetext{
${ }^{1}$ For a careful analysis of Kant's appreciation and refutation of these proofs, see Allen W. Wood, Kant's Rational Theology (Ithaca: Cornell University Press), pp. 95-146.

${ }^{2}$ References to Kant's works are to Immanuel Kant, Gesammelte Schriften, edited by the Royal Prussian (later: German) Academy of Sciences (Berlin: Walter de Gruyter, 1902ff.). Volume numbers are followed by page numbers. Used abbreviations: KRV: Kritik der reinen Vernunft (1781/1787), KPV: Kritik der praktischen Vernunft (1788), KU: Kritik der Urteilskraft (1790); OP: Opus Postumum; R: Reflexionen; RGV: Die Religion innerhalb der Grenzen der bloßen Vernunft (1793); TP: Über den Gemeinspruch: Das mag in der Theorie richtig sein, taugt aber nicht für die Praxis (1793); V-Lo/Dohna: Vorlesungen Logik Dohna-Wundlacken (1792); V-Mo/Collins: Vorlesungen Moralphilosophie Collins (1784-5); V-Mo/Mrongovius: Vorlesungen Moral Mrongovius (1782); V-Mo/Mron II: Vorlesungen Moral Mrongovius II (1784-5); V-MP/Dohna: Vorlesungen Metaphysik Dohna-Wundlacken (1792-3); V-MP/K2: Vorlesungen Metaphysik K2 (1790-1); V-MP/L2/Pölitz: Vorlesungen Metaphysik L2 Pölitz (1790-1); V-MS/Vigilantius: Vorlesungen über die Metaphysik der Sitten Vigilantius (1793-4); V-PP/Herder Praktische Philosophie Herder (1764-5); V-Phil-Th/Pölitz: Vorlesungen
} 
Philosophische Religionslehre nach Pölitz (1783-4); V-Th/Baumbach: Danziger Rationaltheologie nach Baumbach (1784); V-Th/Volckmann: Natürliche Theologie Volckmann nach Baumbach (1783-4); WDO: Was hei $\beta$ t sich im Denken orientiren? (1786). Unless mentioned otherwise, English translations are taken from Immanuel Kant, The Cambridge Edition of the Works of Immanuel Kant, general editors Paul Guyer \& Allen W. Wood (Cambridge: Cambridge University Press, 1992ff.).

${ }^{3}$ See also V-Mo/Collins XXVII:304, 311; V-Mo/Mrongovius XXVII:1456, V-Mo/Mrongovius II XXIX:634; RGV VI:29-31; V-Phil-Th/Pölitz XXVIII:1010, 1011-2, 1065-6, 1071-3. In his Lectures on Ethics by Vigilantius, Kant employs a rich and rhetorical vocabulary for persuading the reader that religion and especially faith in God are important incentives or motives for obeying the moral law. Contra the atheist, he argues that the moral law finds a 'surer entry' by presupposing God's existence, that God as 'executor of the moral laws' is important to 'impel us to the observance of our duties', and that faith in God is 'a helpful means of strengthening us in the observance of the laws', 'an excellent means of reinforcing the laws of duty', and an 'efficacious means' for morality in that 'the morality of actions can be so much improved' (V-MS/Vigilantius XXVII:530).

${ }^{4}$ On the question whether an atheist can be 'tolerated' in society, see also V-PP/Herder XXVII:11.

${ }^{5}$ My translation: 'eine Überzeugung vom Dasein Gottes aus praktischen Gründen'. See also V-Th/Baumbach XXVIII:1246.

${ }^{6}$ See: 'Die Theologie, die sich auf lauter reinen Vernunftgründen gründete, die sich Gott dachte als ein notwendiges Wesen und als den obersten Urheber vorstellte, war der Deismus, die sich Gott als eine Intelligenz, als ein beständiges Wesen, als ein principium der Natur des Reichs der Zwecke dachte, war Theismus, und der Theismus moralis, der sich Gott nicht denkt nach der Natur, sondern nach der Sittlichkeit [...]. Sie betrachtet Gott als den Gesetzgeber des Reichs der Sitten.'

${ }^{7}$ See also WDO VIII: $140-1$.

${ }^{8}$ See also KPV V:146.

${ }^{9}$ Kant's argument for making this statement will be discussed near the end of this section.

${ }^{10}$ For the following account of Kant's moral view of God, see also Lara Denis, 'Kant's Criticisms of Atheism', Kant-Studien 94 (2003), p. 200.

${ }^{11}$ See also V-Th/Baumbach XXVIII:1293.

${ }^{12}$ See also V-Th/Volckmann XXVIII:1181; V-Th/Baumbach: XXVIII:1284; V-Lo/Dohna XXIV:762.

${ }^{13}$ See also V-Mo/Collins XXVII:322; V-Mo/Mrongovius XXVII:1464; Paul Menzer (ed.), Eine Vorlesung Kants über Ethik (Berlin: Pan-Verlag Heise, 1924), p. 121.

${ }^{14}$ See also V-MS/Vigilantius XXVII:581, 723.

${ }^{15}$ See also V-Th/Volckmann XXVIII:1185. In the Opus Postumum, Kant writes that God is to be viewed as 'the personified idea of right and well-being' (OP XXII:108) and can even be equated with the categorical imperative (OP XXI:27) or with 'moral-practical reason giving itself the law' (OP XXI:145). For an analysis of Kant's conception of God in the Opus Postumum, see e.g. Eckart Förster, Kant's Final Synthesis. An Essay on the Opus Postumum (Cambridge: Harvard University Press, 2000), pp. 117-47 and Frederick Rauscher, “'God” without God: Kant's Postulate', Kant e-prints 2.2(2007), pp. 27-62.

${ }^{16}$ See also OP XXI:17, 26, 30, 35, 45, 48, 53, 61, 149; OP XXII:48, 49, 52, 53, 60.

${ }^{17}$ My translation: 'eine Person für die alle Menschenpflichten zugleich dieser (Person) ihre Gebothe sind.' [sic] 
${ }^{18}$ See also V-Th/Volckmann XXVIII:1220.

${ }^{19}$ See also Kant's Lectures on Ethics: V-Mo/Collins XXVII:310, 320-1; V-Mo/Mrongovius XXVII:1463-4. See also Menzer, Eine Vorlesung Kants über Ethik, p. 119. For a defence of our dependence on God's grace and assistance in fulfilling our moral demands, see John E. Hare, The Moral Gap (Oxford: Clarendon Press, 1996).

${ }^{20}$ But see also KU V:450. One of the finest and most meticulous reconstructions of Kant's practical arguments for faith in God can be found in Allen W. Wood, Kant's Moral Religion (Ithaca: Cornell University Press, 1970).

${ }^{21}$ See also Lara Denis, 'Kant's Criticisms of Atheism', pp. 198-219.

${ }^{22}$ My translation: 'alle sittliche Gesetze für leere Einbildung halten'.

${ }^{23}$ See also V-Th/Baumbach XXVIII:1241, 1256; R XVIII:502, 541; V-MP/K2 XXVIII:794; V-MP/L2/Pölitz XXVIII:597; V-MP/Dohna XXVIII:691; V-Mo/Collins XXVII:311; V-Mo/Mrongovius XXVII:1456; Menzer, Eine Vorlesung Kants über Ethik, p. 107.

${ }^{24}$ See also V-Th/Volckman XXVIII:1151; V-Th/Baumbach XXVIII:1246; V-MP-L2/Pölitz XXVIII:597.

${ }^{25}$ See also V-MP-L2/Pölitz XXVIII:597.

${ }^{26}$ My translation: 'der dogmatische [Atheist] (Gottesleugner) verneint die Möglichkeit, der sceptische (Ohngötter) allen Beweis der Wirklichkeit. Jener den Begrif, dieser den Beweisgrund.' [sic] See also: VMo/Collins XXVII:311; V-Mo/Mrongovius XXVII:1456; V-Th/Baumbach XXVIII:1241; Menzer, Eine Vorlesung Kants über Ethik, p. 107.

${ }^{27}$ See also V-Th/Baumbach XXVIII:1257; R XVIII:556.

${ }^{28}$ See also V-Phil-Th/Pölitz XXVIII:1010, where Kant argues that the sceptical atheist 'admits that it is even more impossible to prove that there is no God than to prove that there is one. He denies only that human reason can ever prove God's existence with certainty through speculation; but he sees with equal certainty on the other side that it can never establish that God does not exist.'

${ }^{29}$ See also V-Phil-Th/Pöliz XXVII:1027; V-Th/Baumbach XXVIII:1257.

${ }^{30}$ See also V-Th/Volckmann XXVIII:1151; V-Th/Baumbach XXVIII:1246.

${ }^{31}$ See also V-Th/Volckmann XXVIII:1151: 'Der skeptische leugnet alle gewisse Erkenntnis vom göttlichen Dasein. Es fragt sich, ob der skeptische Atheist Religion haben könne? Allerdings. Er nimmt die Möglichkeit des Daseins Gottes an; deswegen muß er sich so verhalten, als wenn doch ein Gott wäre, und dies ist Religion.' See also V-Th/Baumbach XXVIII:1246: 'Der skeptische Atheist kann eine Religion haben; denn er beweist nicht die Unmöglichkeit des Daseins Gottes; und wenn ich bloß die Möglichkeit Gottes glaube, so kann schon eine Religion stattfinden.'

${ }^{32}$ See also V-Mo/Mrongovius XXVII:1456; Menzer, Eine Vorlesung Kants über Ethik, p. 107.

${ }^{33}$ I wish to thank the reviewer for his invaluable suggestion to emphasise and clarify Kant's own position on this issue.

${ }^{34}$ See also V-Th/Volckmann XXVIII:1174.

${ }^{35}$ See also V-MP-L2/Pölitz XXVIII:597.

${ }^{36}$ See also V-Mo Mrongovius XXVII:1456; Menzer, Eine Vorlesung Kants über Ethik, p. 107.

${ }^{37}$ See also V-Th/Volckmann XXVIII:1151.

${ }^{38}$ Jacqueline Mariña, 'Making Sense of Kant's Highest Good', Kant-Studien 91 (2000), pp. 354-5.

${ }^{39}$ Italics added. Denis, 'Kant's Criticisms of Atheism', p. 204.

${ }^{40}$ Peter Byrne, Kant on God (Hampshire: Ashgate), p. 93. 
${ }^{41}$ See also Rauscher, “'God” without God: Kant's Postulate', p. 46.

${ }^{42}$ See also Paul Guyer, Kant on Freedom, Law, and Happiness (Cambridge \& New York: Cambridge University Press), p. 430.

${ }^{43}$ See also V-Th/Volckmann XXVIII:1221.

${ }^{44}$ Denis, 'Kant's Criticisms of Atheism', p. 212.

${ }^{45}$ Wood, Kant's Moral Religion, p. 160.

${ }^{46}$ For detailed analyses and interpretations of Kant's distinct accounts of the highest good, see especially Sharon Anderson-Gold, 'God and Community: An Inquiry into the Religious Implications of the Highest Good', in P. Rossi and M. Wreen (eds.), Kant's Philosophy of Religion Reconsidered (Bloomington \& Indianapolis: Indiana University Press, 1991), pp. 111-31; Frederick Beiser, 'Moral Faith and the Highest Good', in Paul Guyer (ed.), The Cambridge Companion to Kant and Modern Philosophy (Cambridge: Cambridge University Press, 2006), pp. 588-629; Stephen Engstrom, 'The Concept of the Highest Good in Kant's Moral Theory', Philosophy and Phenomenological Research 92 (1992), pp. 747-80; Christopher Insole, 'The Irreducible Importance of Religious Hope in Kant's Conception of the Highest Good', Philosophy 83 (2008), pp. 333-51; Pauline Kleingeld, 'What Do The Virtuous Hope For? Re-reading Kant's Doctrine of the Highest Good', in Hoke Robinson (ed.), Proceedings of the Eight International Kant Congress (Milwaukee: Marquette University Press, 1995) vol. I(1), pp. 91-112; Andrews Reath, 'Two Conceptions of the Highest Good in Kant', Journal of the History of Philosophy 26 (1988), pp. 593-613; and very recently Eric Watkins, 'The Antinomy of Practical Reason: Reason, the Unconditioned and the Highest Good', in Andrews Reath and Jens Timmermann (eds.), Kant's Critique of Practical Reason: A Critical Guide (Cambridge: Cambridge University Press, 2010), pp. 14567.

${ }^{47}$ See e.g. R XIX:188 where Kant assesses the necessary connection between moral conduct (wohlverhalten) and happiness (wohlbefinden) as a 'bloßes Gedankenwesen'.

${ }^{48}$ See KRV B842; KPV V:110, 125, 128-30, V-Mo/Mron II XXIX:600; V-MS/Vigilantius XXVII:483; VMP/Dohna XXVIII:690, 699; V-MP-K2 XXVIII:776, 791-2, 810; V-Th/Volckmann XXVIII:1132; WDO VIII:139; and R XVIII:464.

${ }^{49}$ Denis, 'Kant's Criticisms of Atheism', p. 202.

${ }^{50}$ See also Denis, 'Kant's Criticisms of Atheism', p. 212.

${ }^{51}$ I wish to thank the reviewer for his thoughtful comments and suggestions. I also wish to thank Bart Vandenabeele and the Research Foundation Flanders for supporting my research. 